\title{
NONWOVENS: BALLISTIC APPLICATIONS AND PATENT SEARCH
}

\author{
Ahmed Hassb Elkarem, \\ Faculty of Engineering, The University of Aberdeen, \\ Aberdeen, United Kingdom
}

\begin{abstract}
Nonwovens are highly demanded in the ballistic protection market due to their lightweight and ultra-high flexibility. Particularly, Kevlar ${ }^{\circledR}$ nonwoven fabrics provide higher energy absorption ability, greater thermal and cutting resistance compared to the other types of nonwoven fabrics. Numerous patents have been published over the past two decades about the use of nonwovens in ballistic applications and creative manufacturing methods and advanced technological solutions. In this report, a detailed overview of the applications of Kevlar ${ }^{\circledR}$ nonwoven fabrics and their unique properties and types is provided. Furthermore, a detailed analysis of the relevant patents that cover the manufacturing methods and composition of ballistic nonwovens is also provided. For each patent, an abstract, description and detailed list of claims are provided. The main goal of to provide better understanding of the use of Kevlar ${ }^{\circledR}$ nonwoven fabrics in bulletproof applications and to review the relevant patented documents which serve as a good reference for further investigations in the area of ballistic nonwovens.
\end{abstract}

\section{INTRODUCTION}

The ballistic armor materials are getting special attention by the military and civilian defense market. Nonwoven and woven composites are preferred in high loading applications [1-4]. For this reason, engineers and researchers started developing new products to satisfy the essential customer's protection needs. Traditionally, soft body armor for ballistic protection was produced from layers of woven fabrics stitched together. However, they now include laminates stacked with nonwoven, unidirectional (UD) layers and sometimes a combination of woven/nonwoven laminates. Considering the UD laminates, fibers within each UD layer are oriented in a parallel orientation and are reinforced with an adhesive polymer resin or matrix such as Kraton that binds the fibers together. In particular, nonwoven fabrics have been effectively utilized in multiple ballistic protection industries. This is attributed to their high flexibility, lightweight and high energy absorption capability [5-7]. A scientific article published by the US Army researchers showed that the Kevlar® (Fig.1 ) needle-punched nonwoven provides around $67 \%$ less structural weight than the woven fabric, while maintaining over $80 \%$ of the ballistic protection capability of the woven fabric. In nonwovens, it has been concluded by many researchers that the modulus of fibers plays the most vital role in ballistic protection. Kevlar ${ }^{\circledR}$ nonwoven fabrics provide higher energy absorption ability compared to the other types of nonwoven fabrics. Previous studies showed that the energy-absorption mechanism of needle-punched fabrics is different from that of the unidirectional fabrics or even woven fabrics where the energy is dissipated in terms of fiber breakage $[8,9]$. On the contrary, there are less fixed and short staple fibers in needle-punched fabrics that can reflect the strain waves. Hence, less fibers failure occurs in nonwoven fabrics.

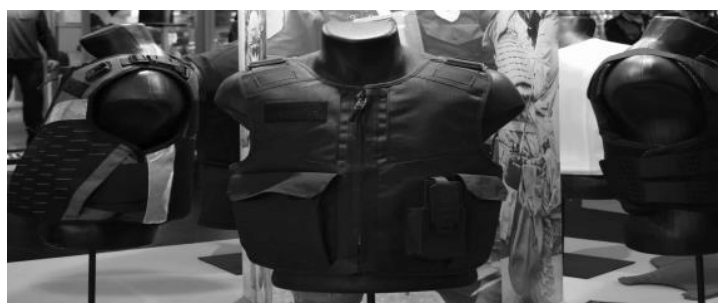

Fig.1: Kevlar®bullet proof vest

As reported by the grand view research, the global body armor market size was valued at USD 2.1 billion in 2018 and is expected to expand at a CAGR of 5.5\% from 2019 to 2025. Increasing focus of defense agencies on ensuring soldier survivability is driving the demand for personal safety equipment and suits. Shortage of ballistic protection fabrics (Fig. 2) and rise in asymmetric warfare in various countries, such as South Korea, Iraq, and India, is further accelerating the industry growth. Kevlar ${ }^{\circledR}$ fibers products are highly 
demanded in numerous nonwoven markets including the military. For instance, Z-11 spunlace is a lightweight fabric, comfortable and saturable. It's known for its superior thermal and flame resistance properties. The fabric is free of binders and resin which makes it maintain the excellent performance. Sontara ${ }^{\circledR}$ products are highly desirable in calendaring rolls, and fire blocking for transportation seating [10]. Both products withstand extreme high temperatures due to their unique low shrinkage ability. Furthermore, the aforementioned products possess high cutting resistance as well as high fabric integrity and dimensional stability.

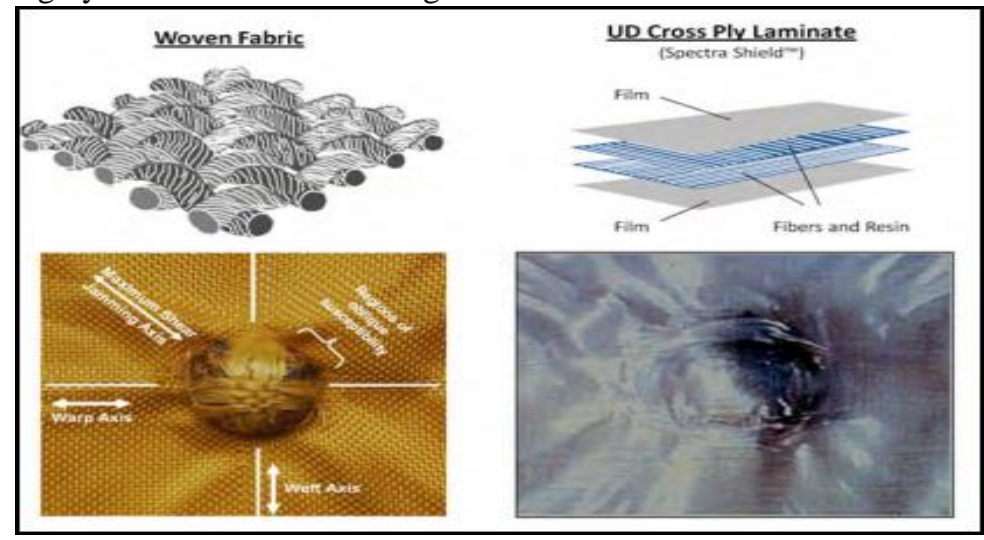

Fig.2: Fabrics for ballistic protection [11]

Investigations and initial evaluation of patents

\begin{tabular}{|c|c|c|c|c|}
\hline Patent Number & $\begin{array}{l}\text { Publication } \\
\text { Date }\end{array}$ & Title & Assignee & Note \\
\hline $\begin{array}{l}\text { CN103526453A } \\
{[12]}\end{array}$ & 01-10-2013 & $\begin{array}{l}\text { Method for making } \\
\text { bulletproof composite } \\
\text { materials through aramid } \\
\text { fiber non-woven cloth }\end{array}$ & $\begin{array}{l}\text { Beijing Leite } \\
\text { New } \\
\text { Technology } \\
\text { Industrial } \\
\text { Company, } \\
\text { China. }\end{array}$ & $\begin{array}{l}\text { - High in safety margin, } \\
\text { - Low in weight } \\
\text { - Capable of obviously } \\
\text { improving safety of war } \\
\text { fighters }\end{array}$ \\
\hline $\begin{array}{l}\text { WO2017116649A1 } \\
{[13]}\end{array}$ & 07-06-2017 & $\begin{array}{lr}\text { Ballistic } & \text { Materials } \\
\text { incorporating } & \text { spunlaced } \\
\text { Nonwovens. } & \end{array}$ & $\begin{array}{l}\text { Tex Tech } \\
\text { industries, } \\
\text { Inc., US }\end{array}$ & $\begin{array}{ll}\text { - } & \text { Ballistic material made } \\
\text { from } \\
\text { spunlace nonwoven fibers } \\
\text { mechanically entangled } \\
\text { into } \\
\text { woven ballistic fabric } \\
\text { - Nonwoven may comprise } \\
\text { low denier fibers providing } \\
\text { for a highly } \\
\text { dense ballistic product }\end{array}$ \\
\hline $\begin{array}{l}\text { US007631405B2 } \\
{[14]}\end{array}$ & 09-05-2006 & $\begin{array}{l}\text { Enhanced Energy Absorbing } \\
\text { Materials. }\end{array}$ & $\begin{array}{l}\text { Tex Tech } \\
\text { industries, } \\
\text { Inc., US }\end{array}$ & $\begin{array}{ll}- & \text { Dense } \\
- & \text { highly stable } \\
\text { - } & \text { Excellent ballistic perform } \\
\text { ance at low areal densities } \\
\text { and thicknesses. }\end{array}$ \\
\hline
\end{tabular}


International Journal of Engineering Applied Sciences and Technology, 2020

Vol. 5, Issue 4, ISSN No. 2455-2143, Pages 62-65

Published Online August 2020 in IJEAST (http://www.ijeast.com)

\begin{tabular}{|c|c|c|c|c|}
\hline $\begin{array}{l}\text { US006651543B2 } \\
{[15]}\end{array}$ & $11-25-2003$ & $\begin{array}{l}\text { Lightweight soft body armor } \\
\text { product }\end{array}$ & $\begin{array}{l}\text { PTI ARMOR } \\
\text { SYSTEMS } \\
\text { LLC Armor } \\
\text { Works } \\
\text { Enterprises } \\
\text { LLC PTI } \\
\text { Materials LLC }\end{array}$ & $\begin{array}{l}\text { - A ballistic panel } \\
\text { provided for being } \\
\text { incorporated into a } \\
\text { lightweight soft body- } \\
\text { armor product adapted for } \\
\text { covering an area of } \\
\text { the body. }\end{array}$ \\
\hline $\begin{array}{l}\text { US00938764.4B1 } \\
{[16]}\end{array}$ & 07-12-2016 & $\begin{array}{l}\text { Ballistic resistant material } \\
\text { with nonorthogonal stitching }\end{array}$ & $\begin{array}{l}\text { KENNON } \\
\text { PRODUCTS, } \\
\text { INC., US }\end{array}$ & $\begin{array}{l}\text { - The invention provides } \\
\text { ballistic resistant armor } \\
\text { including a first ballistic } \\
\text { resistant layer including } \\
\text { non-woven material }\end{array}$ \\
\hline
\end{tabular}

\section{SUMMARY \& CONCLUSIONS}

The demanded for lightweight effective ballistic protection nonwovens is rapidly increasing. Particularly, Kevlar® nonwoven fabrics provide higher energy absorption ability, greater thermal and cutting resistance compared to the other types of nonwoven fabrics. Numerous patents have been published over the past two decades about the use of nonwovens in ballistic applications and creative manufacturing methods and advanced technological solutions. In this report, a detailed overview of the applications of Kevlar ${ }^{\circledR}$ nonwoven fabrics and their unique properties and types was provided. Furthermore, a detailed analysis of the relevant patents that cover the manufacturing methods and composition of ballistic nonwovens was described in detail. For each patent, an abstract, description and detailed list of claims are outlined. The main goal of this study was to provide better understanding of the use of Kevlar® nonwoven fabrics in bulletproof applications and to review the relevant patented documents which serve as a good reference for further investigations in the area of ballistic nonwovens.

\section{REFERENCES}

1 Elamin, M., Li, B., \& Tan, K. T. (2018). Impact damage of composite sandwich structures in arctic condition. Composite Structures, 192, 422-433.

2 Khan, M. H., Elamin, M., Li, B., \& Tan, K. T. (2018). X-ray micro-computed tomography analysis of impact damage morphology in composite sandwich structures due to cold temperature arctic condition. Journal of Composite Materials, 52(25), 3509-3522.

3 Elamin, M., Li, B., \& Tan, K. T. (2018). Impact Performance of Stitched and
Unstitched Composites in Extreme Low Temperature Arctic Conditions. Journal of Dynamic Behavior of Materials, 4(3), 317327

4 TAN, K., ELAMIN, M., \& LI, B. (2017). Impact Performance and Damage Behavior of Composite Sandwich Structures in Arctic Condition. In Proceedings of the American Society for Composites-Thirty-second Technical Conference.

5 Hasan Kocer LAMINATED AND HYBRID SOFT ARMOR SYSTEMS FOR BALLISTIC APPLICATIONS.

6 https://advancedtextilessource.com/2015/12/ 04/better-ballistics-part-i/

7 https://www.grandviewresearch.com/industr $\mathrm{y}$-analysis/body-armor-market

8 Elamin, M., \& Varga, J. (2020). Plate impact method for shock physics testing. Material Sci \& Eng, 4(1), 31-35.

9 Mohammed, M. (2018). IMPACT AND POST IMPACT RESPONSE OF COMPOSITE SANDWICH STRUCTURES IN ARCTIC CONDITION . (Electronic Thesis or Dissertation). Retrieved from https://etd.ohiolink.edu/

10 https://www.jacob-holm.com/us/en-us/ourmarkets/high-performance-materials/aramidfabrics/sontara-kevlar-sl-type-z-11/

11 https://www.dupont.com/military-lawenforcement-and-emergency-response/bodyarmor.html

12 Method for making bulletproof composite materials through aramid fiber non-woven cloth, Patent No. CN103526453A, Beijing Leite New Technology Industrial Company, China.

13 Ballistic Materials incorporating spunlaced Nonwovens, Patent No. WO2017116649A1, Tex Tech industries, Inc., US 
International Journal of Engineering Applied Sciences and Technology, 2020

Vol. 5, Issue 4, ISSN No. 2455-2143, Pages 62-65

Published Online August 2020 in IJEAST (http://www.ijeast.com)

14 Enhanced Energy Absorbing Materials, Patent No. US007631405B2, Tex Tech industries, Inc., US

15 Lightweight soft body armor product, Patent No. US006651543B2, PTI ARMOR SYSTEMS LLC Armor Works Enterprises LLC PTI Materials LLC

16 Ballistic resistant material with nonorthogonal stitching, Patent No. US00938764.4B1, KENNON PRODUCTS, INC., US 